Diabetologia 9, 210-216 (1973)

(C) by Springer-Verlag 1973

\title{
The Pancreatic $\beta$-Cell Recognition of Insulin Secretagogues
}

\author{
IV. Islet Uptake of Sulfonylureas
}

\author{
B. Hellman, J. Sehlin and I.-B. Täljedal \\ Department of Histology, University of Umeå, Umeå, Sweden
}

Received: September 7, 1972, accepted: January 12, 1973

Summary. The study was aimed at testing the hypothesis that sulfonylureas do not readily penetrate the pancreatic $\beta$-cells but more probably stimulate insulin release by a direct action on the $\beta$-cell plasma membrane. Uptake of radioactively labelled tolbutamide and glibenclamide by microdissected pancreatic islets of obesehyperglycemic mice was compared with the uptake of 3-O-methyl-D-glucose, to which the $\beta$-cells are permeable. In contrast to tolbutamide, glibenclamide was taken up in amounts exceeding the 3-O-methyl-D-glucose space of islets incubated in the absence of serum albumin. Uptake of the sulfonylureas was easily reversible. It was depressed by serum albumin, whereas glucose, leucine or diazoxide had no effects. Antimycin A, $p$-chloromercuriphenylsulfonic acid and chlorpromazine, all of which increase the uptake of extracellular space markers, strongly stimulated. the islet uptake of tolbutamide and glibenclamide but had no effect on the uptake of glibenclamide by subcellular particles of homogenized islets. The results suggest that sulfonylureas bind reversibly to islet tissue but are normally restricted to the outside of the $\beta$-cells.

Key words: Glibenclamide, insulin release, pancreatic islets, sulfonylurea, tolbutamide.
Sulfonylurea compounds are widely used in the treatment of diabetes mellitus. These drugs may have direct effects on several tissues, but it is generally assumed that their therapeutic value is mainly due to stimulation of insulin release (Loubatières, 1968; Grodsky, 1971). The sensitivity of the pancreatic $\beta$ cells to sulfonylureas is poorly understood. It seems reasonable to expect that insight into their mode of action would promote the understanding of physiological insulin release as well. In a previous communication we reported that microdissected pancreatic islets have a tolbutamide space which is equal to their sucrose and mannitol spaces and significantly smaller than their 3-O-methyl-D-glucose space (Hellman et al., 1971a). These observations indicated that tolbutamide does not readily penetrate into $\beta$-cells. Consequently it was suggested that the $\beta$-cell plasma membrane contains a tolbutamide receptor, which is responsible for the recognition of sulfonylureas as insulin secretagogues. These results are probably representative of the in vivo situation, since the incubations were performed with albumin present in the media. The fact that sulfonylureas have a great affinity for albumin (Judis, 1972) makes it also interesting to study the effect of albumin on the islet uptake of sulfonylureas. This seems particularly important in view of conflicting reports that the $\beta$-cells may be permeable to glibenclamide (Howell and Lacy, 1969), another sulfonylurea with pronounced insulin-releasing ability. In the present paper we report data on the uptake of glibenclamide and tolbutamide by microdissected islets from obese-hyperglycemic mice. The effects of albumin and other compounds on the uptake of these drugs have been studied with particular reference to the question whether or not sulfonylureas readily enter the pancreatic $\beta$-cells.

\section{Materials and Methods}

Chemicals. 1-Butyl-3-[p-tolyl- $\left({ }^{35} \mathrm{~S}\right)$ sulfonyl]urea (tolbutamide) and 3-O-methyl-D-(1-3 $\mathrm{H})$ glucose were obtained from the Radiochemical Centre, Amersham, England. N4-[2-(5-chloro-2-methoxy-benzamido)-ethyl]-phenyl-sulfonyl-N'-cyclohexyl-(14C) urea (glibenclamide) as well as non-radioactive glibenclamide were donated by Farbwerke Hoechst, Frankfurt/M., Germany. 7-Chloro-3methyl-1,2,4-benzothiadiazine-1,1-dioxide (diazoxide) was a gift from Schering Corp., Bloomfield, N.J., U.S.A. $p$-Chloromercuriphenylsulfonic acid (PCMBS) and antimycin A were from Sigma Chemical, Co., St. Louis, Mo., U.S.A., and chlorpromazine chloride from $\mathrm{AB}$ Leo, Helsingborg, Sweden. Human serum albumin (grade A, less than $2 \%$ other proteins) was from Kabi AB, Stockholm, Sweden.

Preparation of islets. Adult male obese-hyperglycemic mice (gene symbol: $o b / o b$ ) from the Umea colony were starved overnight. Fresh pancreatic islets were isolated by free hand microdissection (Hellerström, 1964) in gassed $\left(\mathrm{O}_{2}+\mathrm{CO}_{2}, 95: 5\right)$ Krebs-Ringer bicarbonate buffer (Umbreit et al., 1964). No collagenase was used in the isolation procedure.

Incubations. All incubations were performed at $37^{\circ} \mathrm{C}$, using Krebs-Ringer bicarbonate buffer equilibrated with $\mathrm{O}_{2}+\mathrm{CO}_{2}(95: 5)$ as the basal medium. Additions to the media are described in the legends to figures and tables. Uptake of radioactively labelled sulfonylureas by incubated islets was studied in relation to the simultaneous uptake of 3-O-methyl-D- $\left(1-{ }^{3} \mathrm{H}\right)$ glucose, to which the $\beta$-cells are permeable (Hellman et al., $1971 \mathrm{~b}$ ). This design made it possible to estimate the cellular uptake of sulfonylureas without washing the islets after incubation. In view of the pharmacological potency of glibenclamide, it was of interest to study the islet uptake of this drug at concentrations as low as $10 \mu \mathrm{M}$. To reduce the risk of an interference between the drug and the space marker, 3-O-methyl-D-glucose was used at a concentration of only 1.3 $\mu \mathrm{M}$ in these experiments. This concentration is several orders of magnitude lower than those previously used (Hellman et al., 1971 b), which introduces a source of uncertainty as to the physical counterpart of the apparent 
3.O-methyl-D-glucose space. A series of control experiments revealed, however, that islets incubated in a medium containing both $1.3 \mu \mathrm{M} 3 . \mathrm{O}$-methyl-D- $\left(1{ }^{3} \mathrm{H}\right)$ glucose and $0.5 \mathrm{mM}$ (14 C)urea had an apparent $3 . \mathrm{O}$ methyl-D-glucose space that was not smaller than the urea space. Uptake of glibenclamide in excess of the 3-O-methyl-D-glucose space therefore means a greater uptake of the drug than would be expected as the result of passive distribution in the total tissue water.

One series of experiments was performed to study the uptake of glibenclamide by subcellular islet particles. In each exporiment 25 to 30 islots were homogenized in 75 ul basal medium, using a microscale pestle homogenizer made of perspex. After centrifugation at about $400 \mathrm{~g}$ for $10 \mathrm{~min}$, $10 \mu \mathrm{I}$ samples of the supernatant were assayed for protein (Lowry et al., 1951) or were incubated for $90 \mathrm{~min}$ with $90 \mu \mathrm{l}$ medium containing glibenclamide, 3-O-methyl-Dglucose, and test substances as described in the legend to Table 2. The mixtures of homogenate and medium were then filtered on membrane filters with a pore size of 0.5 micron (Oxoid Ltd., England). After drying, the filters were analyzed for ${ }^{3} \mathrm{H}$ and ${ }^{14} \mathrm{C}$.

Weighing of islets and counting of radioactivity. After incubation the islets were placed on pieces of aluminum foil and with the aid of a micropipette they were freed of as much contaminating fluid as possible. This procedure was standardized to take only a few seconds, after which the islets were plunged into isopentane cooled to its melting-point $\left(-160^{\circ} \mathrm{C}\right)$. The isiets were then freeze-dried $\left(-40^{\circ} \mathrm{C}, 0.001 \mathrm{~mm} \mathrm{Hg}\right)$ overnight and were weighed on a quartz-fiber balance. The weighed islets were dissolved in hyamine and analyzed for ${ }^{3} \mathrm{H},{ }^{14} \mathrm{C}$, and ${ }^{35} \mathrm{~S}$ in a liquid scintillation spectrometer as previously described (Hellman et al., $1971 \mathrm{a}, \mathrm{b})$.

Calculation of results. Results are expressed as mmol sulfonylurea taken up per unit dry weight of islets. In addition to the total uptake, data on the uptake in excess of the 3-O-methyl-D-glucose space will be given. The term "space" is defined by the expression: (c.p.m. in tissue)/(c.p.m. per unit volume of medium). Uptake in excess of the 3.0-methyl-D-glucose space is defined as: (mmol sulfonylurea in islet) - (concentration of sulfonylurea in medium) $\times$ (3-O-methyl-D-glucose space). This expression will be negative when the amount of sulfonylurea taken up is less than that which corresponds to a passive distribution of the drug in the 3-O-methyl-D-glucose space.

\section{Results}

Time-course of sulfonylurea uptake and release

Fig. 1 shows the time course of islet uptake of sulfonylurea in the absence of serum albumin. Tolbut. amide did not exceed the 3-0-methyl-D-glucose space, whereas glibenclamide accumulated to high levels. The uptake of glibenclamide was apparently a linear function of its concentration in the range 10 to $100 \mu \mathrm{M}$ (Fig. 2). As shown in Fig. 3, islets preloaded with radioactive glibenclamide rapidly lost their label upon transfer to a medium free from glibenclamide. Tolbutamide was even more rapidly washed out from islets preloaded with this drug (Fig. 3).

\section{Effect of albumin on the uptake of sulfonylurea}

The demonstration of a marked accumulation of glibenclamide in islets incubated in the absence of serum albumin does not mean that the drug is taken up in large amounts in vivo as well. To test whether the presence of albumin would affect the uptake of this drug, islets were incubated for $60 \mathrm{~min}$ with $20 \mu \mathrm{M}{ }^{14} \mathrm{C}$ labelled glibenclamide $(52 \mathrm{mCi} / \mathrm{mmol})$ and $1.3 \mu \mathrm{M} 3$ O-methyl-D-(1- $\left.{ }^{3} \mathrm{H}\right)$ glucose $(3 \mathrm{Ci} / \mathrm{mmol})$ in basal medium containing or lacking $0.3 \%(\mathrm{w} / \mathrm{v})$ serum albumin. The mean value \pm S.E. $(n=8)$ for uptake of glibenclamide in excess of the $3 \mathrm{~m} O$-methyl-D-glucose space was $0.52+0.04 \mathrm{mmol} / \mathrm{kg}$ dry islet for incubations in albumin-free medium, and $-0.06 \pm 0.003 \mathrm{mmol} / \mathrm{kg}$ dry islet for incubations in the presence of albumin. This effect of albumin was significant at the $0.1 \%$ level.

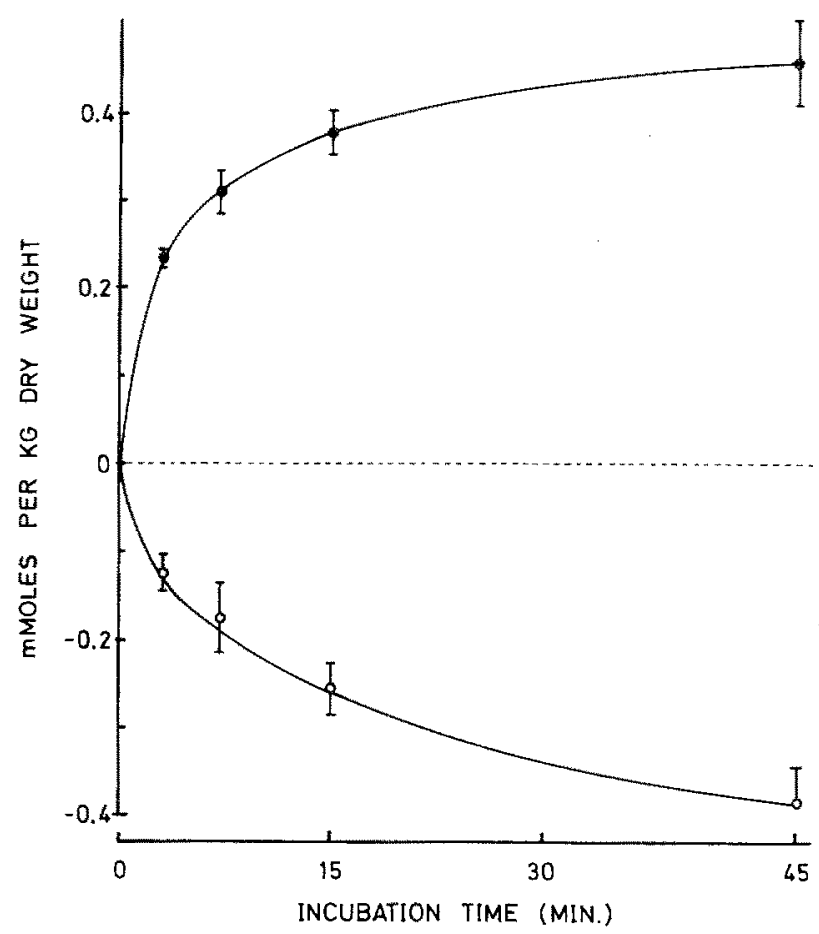

Fig. 1. Time-course of sulfonylurea uptake in the absence of serum albumin. After preincubation for $30 \mathrm{~min}$ in basal medium, islets were incubated for different periods of time in media containing either $20 \mu \mathrm{M}{ }^{14} \mathrm{C}$-labelled glibenclamide $(52 \mathrm{mCi} / \mathrm{mmol})$ or $0.3 \mathrm{mM}{ }^{35} \mathrm{~S}$-labelled tolbutamide $(17 \mathrm{mCi} / \mathrm{mmol})$. In addition to sulfonylurea, the media contained 3-O-methyl. D- $\left(1-{ }^{3} \mathrm{H}\right)$ glucose at a concen * tration of $1.3 \mu \mathrm{M}(3 \mathrm{Ci} / \mathrm{mmol})$ in the case of glibenclamide and $0.1 \mathrm{mM}(150 \mathrm{mCi} / \mathrm{mmol})$ in the case of tolbutamide. The points show islet uptake (mmol/kg dry islet) of gliben. clamide (C) and tolbutamide $(O)$ corrected for label in the 3-O-methyl-D-glucose space. Bars denote S.E. for 6 experiments

The effeot of albumin on the islet uptake of glibenclamide is also demonstrated in Fig. 4. When islets were preloaded and brought to equilibrium with ${ }^{14} \mathrm{C}$ labelled glibenclamide in an albumin-free medium, the addition of serum albumin to the radioactive medium resulted in a rapid loss of ${ }^{14} \mathrm{C}$ from the islets. The new equilibrium was apparently the same as that observed when islets were exposed to ${ }^{14} \mathrm{C}$-labelled glibenclamide and albumin throughout the whole incubation. 


\section{Effect of collagenase on the uptake of glibenclamide}

Islets microdissected free-hand are surrounded by a delicate connective-tissue capsule, whereas this capsule is lost in the preparation of isolated islets by collagenase digestion (Lernmark,1971). To test whether the presence of the capsule affects the uptake of sulfonylurea, we compared the uptake of glibenclamide in ordinarily microdissected islets with that in islets

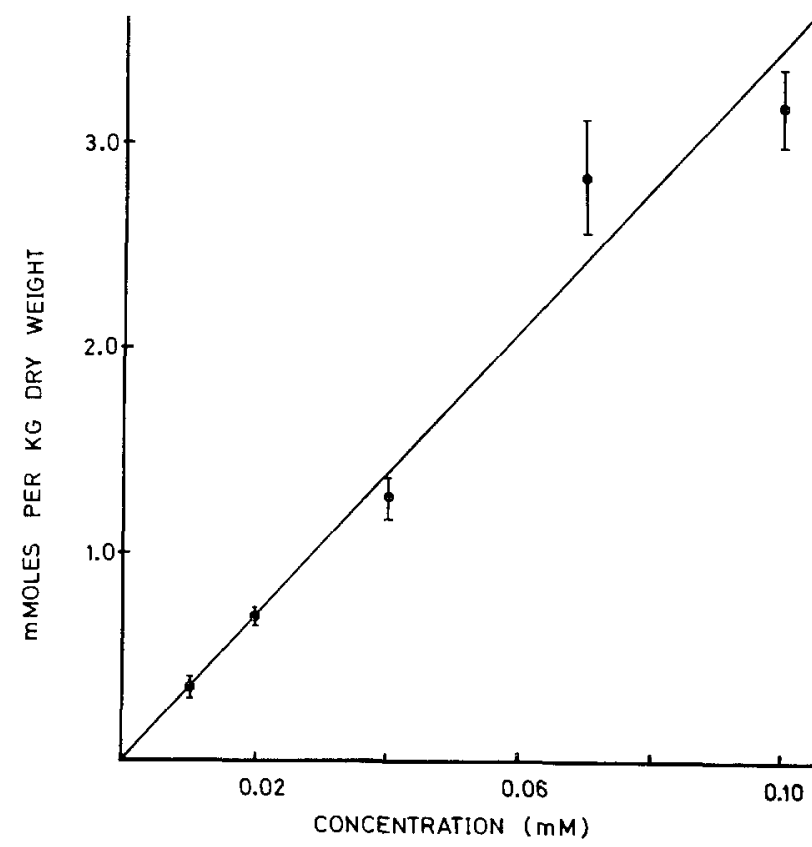

Fig. 2. Concentration dependence of glibenclamide uptake in the absence of serum albumin. After preincubation for $30 \mathrm{~min}$ in basal medium, islets were incubated for $60 \mathrm{~min}$ with different concentrations of ${ }^{14} \mathrm{C}$-labelled glibenclamide (11 to $52 \mathrm{mCi} / \mathrm{mmol}$ ) and $1.3 \mu \mathrm{M}$ 3-O-methyl-D- $\left(1-{ }^{3} \mathrm{H}\right)$ glucose $(3 \mathrm{Ci} / \mathrm{mmol})$. The points show islet uptake of glibenclamide ( $\mathrm{mmol} / \mathrm{kg}$ dry islet) corrected for label in the 3-O-methyl-D-glucose space. Bars denote S.E. for 5 to 8 experiments

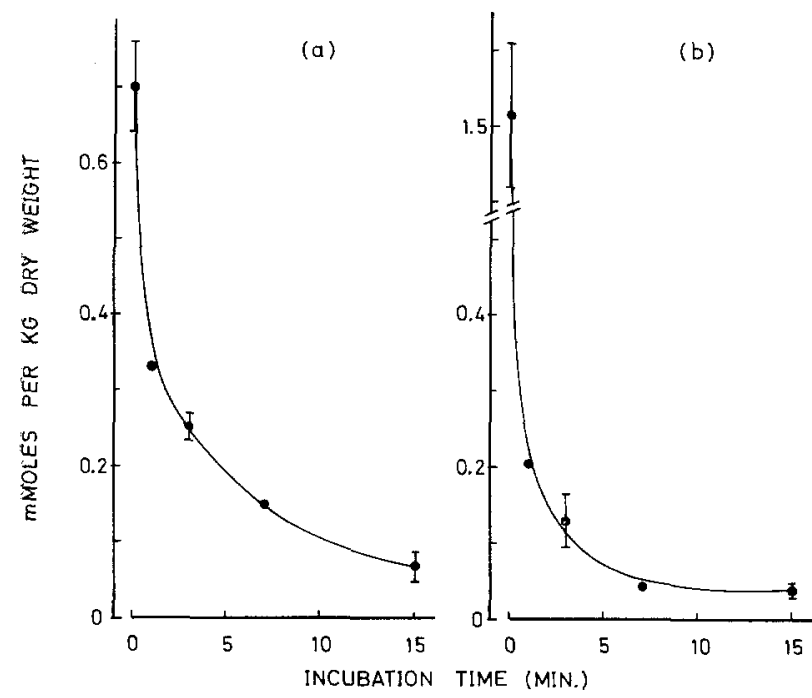

Fig. 3. Loss of radioactivity from islets preloaded with ${ }^{14} \mathrm{C}$-labelled glibenclamide $(a)$ or ${ }^{35} \mathrm{~S}$-labelled tolbutamide (b). Islets were preincubated for $45 \mathrm{~min}$ in basal medium supplemented with either $20 \mu \mathrm{M}{ }^{14} \mathrm{C}$-labelled glibenclamide $(52 \mathrm{mCi} / \mathrm{mmol})$ or $0.3 \mathrm{mM}{ }^{35} \mathrm{~S}$-labelled tolbutamide $(17$ $\mathrm{mCi} / \mathrm{mmol})$. They were then incubated for various periods of time in media not containing sulfonylureas or 3-Omethyl-D-glucose. The islet contents of sulfonylurea (mmol/kg dry islet) are given as mean values for 2 to 7 experiments. Bars denote S.E. for 4 to 7 experiments

Table 1. Effects of various compounds on the istet uptake of sulfonylureas in the absence of serum albumin

\begin{tabular}{|c|c|c|c|c|c|}
\hline \multirow[t]{3}{*}{ Test substance } & \multirow{3}{*}{$\begin{array}{l}\text { No. of } \\
\text { expts. }\end{array}$} & \multicolumn{4}{|c|}{ Sulfonylurea uptake (mmol/kg dry islet) } \\
\hline & & \multicolumn{2}{|l|}{ Uncorrected } & \multicolumn{2}{|c|}{ Corrected for $30 \mathrm{MG}$ space } \\
\hline & & Test value & $\begin{array}{l}\text { Test minus } \\
\text { control }\end{array}$ & Test value & $\begin{array}{l}\text { Test minus } \\
\text { control }\end{array}$ \\
\hline \multicolumn{6}{|l|}{ Uptake of glibenclamide } \\
\hline D-glucose, $20 \mathrm{mM}$ & 7 & $0.73 \pm 0.05$ & $-0.02 \div 0.05$ & $0.64\rfloor 0.05$ & $0.02 \pm 0.03$ \\
\hline L-leucine, $20 \mathrm{mM}$ & 7 & $0.71 \pm 0.03$ & $-0.04 \div 0.05$ & $0.61 \pm 0.03$ & $0.00 \pm 0.04$ \\
\hline Diazoxide, $125 \mathrm{ug} / \mathrm{ml}$ & 7 & $0.74+0.06$ & $0.02 \pm 0.06$ & $0.63 \pm 0.06$ & $0.02 \pm 0.06$ \\
\hline PCMBS, $0.5 \mathrm{mM}$ & 7 & $1.98 \pm 0.08$ & $1.24 \pm 0.06^{\mathrm{a}}$ & $1.81 \pm 0.08$ & $1.19 \pm 0.07^{\mathrm{a}}$ \\
\hline Antimycin $\mathrm{A}, 10 \mu \mathrm{M}$ & 7 & $1.61 \pm 0.13$ & $0.90 \pm 0.12^{\mathrm{a}}$ & $1.46 \pm 0.14$ & $0.85 \pm 0.12^{\mathrm{a}}$ \\
\hline Chlorpromazine, $0.5 \mathrm{mM}$ & 8 & $3.92 \pm 0.20$ & $2.92 \div 0.22^{\mathrm{a}}$ & $3.55 \pm 0.21$ & $2.78 \pm 0.24^{a}$ \\
\hline \multicolumn{6}{|l|}{ Uptake of tolbutamide } \\
\hline PCMBS, $0.5 \mathrm{mM}$ & 8 & $3.75 \pm 0.23$ & $2.50 \pm 0.23^{a}$ & $1.05 \pm 0.11$ & $1.31 \pm 0.12^{\mathrm{a}}$ \\
\hline Antimycin $\mathrm{A}, 10 \mu \mathrm{MI}$ & 8 & $3.41 \pm 0.11$ & $2.13 \pm 0.11^{\mathrm{a}}$ & $0.87 \pm 0.03$ & $1.13 \pm 0.03^{\mathrm{a}}$ \\
\hline
\end{tabular}

After preincubation for $30 \mathrm{~min}$ in basal medium supplemented with one of the listed test substances, islets were incubated for $60 \mathrm{~min}$ with radioactive sulfonylurea as well as test substance as indicated. In each experiment parallel control incubations were also performed in the absence of test substance. The incubation media contained $20 \mu \mathrm{M}$ ${ }^{14} \mathrm{C}$-labelled glibenclamide $(52 \mathrm{mCi} / \mathrm{mmol})$ and $1.3 \mu \mathrm{M}$ 3-O-methyl-D- $\left(1{ }^{3} \mathrm{H}\right)$ glucose $(3 \mathrm{Ci} / \mathrm{mmol})$ in studies of gliben-

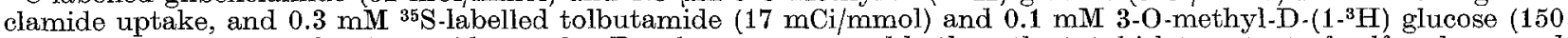
$\mathrm{mCi} / \mathrm{mmol}$ ) in studies of tolbutamide uptake. Results are expressed both as the total islet content of sulfonylurea and as the content of sulfonylurea in excess of the 3-O-methyl-D-glucose (3OMG) space. Mean values \pm S.E. are given for each test condition as well as for the differences between parallel test and control incubations.

a $P<0.001$. 
which had also been treated with collagenase to remove the peri-insular connective tissue. The incubations, which were performed for $45 \mathrm{~min}$ with $20 \mu \mathrm{M}$ glibenclamide in the presence of $0.3 \%(w / v)$ serum al-

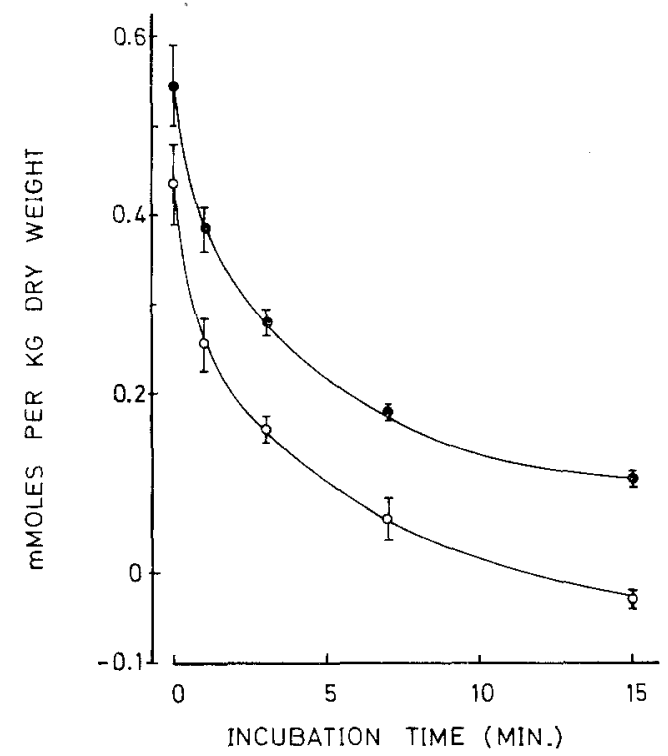

Fig. 4. Removal of islet-bound glibenclamide with serum albumin. Islets were preincubated for $45 \mathrm{~min}$ in basal medium free from albumin but supplemented with $20 \mu \mathrm{M}$ ${ }^{14} \mathrm{C}$-labelled glibenclamide $(52 \mathrm{mCi} / \mathrm{mmol})$ and $1.3 \mu \mathrm{M}$ 3-O-methyl-D- $\left(1{ }^{3} \mathrm{H}\right)$ glucose $(3 \mathrm{Ci} / \mathrm{mmol})$. They were then incubated for different periods of time in a medium containing ${ }^{14} \mathrm{C}$-glibenclamide and 3-O-methyl-D-(1-3 $\left.\mathrm{H}\right)$ glucose as during preincubation and, in addition, $0.3 \%(\mathrm{w} / \mathrm{v})$ serum albumin. The points represent mean values \pm S.E. for 6 experiments and denote islet content of glibenclamide (mmol/kg dry islet) with (O) and without correction for label in the 3 -O-methyl-D-glucose space

bumin, revealed no difference between the two groups of islets; in neither group was the apparent glibenclamide space greater than that of 3-O-methyl-D-glucose.

\section{Effects of various compounds on the uptake of sulfonyl- urea}

The insulin-releasing action of sulfonylureas can be potentiated by glucose or leucine (Grodsky, 1971) and counteracted by diazoxide (Loubatières, 1968). Table 1 shows that none of these substances had any significant effect on the islet uptake of tolbutamide and glibenclamide. However, the uptake of these drugs was greatly increased by $0.5 \mathrm{mM} p$-chloromercuriphenylsulfonic acid (PCMBS), $10 \mu \mathrm{M}$ antimycin $A$ or $0.5 \mathrm{mM}$ chlorpromazine. Previous results had indicated that treatment with PCMBS for $1 \mathrm{~h}$ results in an increased permeability of the $\beta$-cell plasma membrane to small organic solutes which are normally restricted to the extracellular space (Bloom et al., 1972). To test whether antimycin $\mathrm{A}$ and chlorpromazine have a similar effect, islets were incubated for $60 \mathrm{~min}$ in albumin-free media containing $0.3 \mathrm{mM}\left(\mathrm{U}_{-}{ }^{14} \mathrm{C}\right)$ sucrose $(50 \mathrm{mCi} /$ mmol) and $0.1 \mathrm{mM}$ 3-0-methyl-D(1- $\left.{ }^{3} \mathrm{H}\right)$ glucose (150 $\mathrm{mCi} / \mathrm{mmol}$ ). When $10 \mathrm{uM}$ antimycin A was also present in the medium, there was a significant $(P<0.005)$ increase of the sucrose space corresponding to $0.21 \pm$

Table 2. Effects of PCMBS, antimycin $A$ and chlorpromazine on the uptake of glibenclamide by homogenized islets

\begin{tabular}{|c|c|c|c|}
\hline \multirow[t]{2}{*}{ Test substance } & \multirow[t]{2}{*}{$\begin{array}{l}\text { No. of } \\
\text { expts. }\end{array}$} & \multicolumn{2}{|c|}{$\begin{array}{l}\text { Glibenclamide uptake } \\
\text { (mmol/kg protein) }\end{array}$} \\
\hline & & Test value & $\begin{array}{l}\text { Test minus } \\
\text { control }\end{array}$ \\
\hline $\begin{array}{l}\text { PCMBS, } \\
0.5 \mathrm{mM}\end{array}$ & 6 & $0.48 \pm 0.04$ & $-0.06 \pm 0.02^{\mathrm{a}}$ \\
\hline $\begin{array}{l}\text { Antimycin A, } \\
10 \mu \mathrm{M}\end{array}$ & 6 & $0.58 \pm 0.08$ & $0.06 \pm 0.06$ \\
\hline $\begin{array}{l}\text { Chlorpromazine, } \\
0.5 \mathrm{mM} \text {. }\end{array}$ & 5 & $0.57 \pm 0.07$ & $-0.11 \pm 0.13$ \\
\hline
\end{tabular}

Samples of islet homogenates were assayed for protein or were incubated for 90 min with basal medium containing $20 \mu \mathrm{MI}{ }^{14} \mathrm{C}$-labelled glibenclamide $(52 \mathrm{mCi} / \mathrm{mmol})$ and $1.3 \mu \mathrm{M}$ 3-O-methyl-D-(1-3 $\mathrm{H})$ glucose $(3 \mathrm{Ci} / \mathrm{mmol})$. Control incubations were performed without further additives, whereas test incubations were carried out in media also containing $0.5 \mathrm{mM}$ PCMBS, $10 \mu \mathrm{M}$ antimycin $\mathrm{A}$ or 0.5 $\mathrm{mM}$ chlorpromazine. The mixtures of homogenate and medium were then filtered and the retained particles analyzed for ${ }^{3} \mathrm{H}$ and ${ }^{14} \mathrm{C}$. After correction for label in the 3-O-methyl-D-glucose space, the amounts of particlebound glibenclamide were calculated per unit protein of the incubated homogenate. Results are given as mean values \pm S.E. for test incubations as well as for the differences between paired test and control incubations.

$$
\text { a } P<0.05 \text {. }
$$

$0.03 \mathrm{mmol}$ sucrose $/ \mathrm{kg}$ dry islet (mean value \pm S.E. for 6 experiments). Similarly, $0.5 \mathrm{mM}$ chlorpromazine caused an increase of the sucrose space corresponding to $0.56+0.11 \mathrm{mmol}$ sucrose $/ \mathrm{kg}$ islet (mean value \pm S.E. for 4 experiments; $P<0.02$ ). After incubation with this compound there was no difference between the sucrose and 3-O-methyl-D-glucose spaces.

The above results suggest that PCMBS, antimycin $A$ and chlorpromazine increased the islet uptake of tolbutamide and glibenclamide by increasing the $\beta$-cell permeability to sulfonylureas. If this interpretation is correct, PCMBS, antimycin $\mathrm{A}$ and chlorpromazine would not be expected to enhance the uptake of sulfonylureas by fragments of homogenized islets. To test this prediction, homogenized islets were incubated with ${ }^{14} \mathrm{C}$-labelled glibenclamide, and the uptake by subcellular particles was measured after filtration on oxoid filters. Table 2 shows that PCMBS, antimycin A or chlorpromazine did not stimulate the uptake of glibenclamide by the particles retained by the filters. On the contrary, PCMBS significantly inhibited the uptake of glibenclamide by subcellular particles, which suggests that part of the uptake may involve binding to thiol groups. It should be pointed out that the particles retained by oxoid filters are not representative of the whole islet homogenate, which probably explains the lower values obtained in this type of experiments as compared with the data of Table 1. 


\section{Discussion}

The concentrations of sulfonylureas used in the present study were chosen with a view to the pharmacological potency of these drugs. Studies on the release of insulin from isolated rat islets showed that the threshold dose for stimulation with glibenclamide $(1.2 \mu \mathrm{M})$ was only $1 / 100$ of that required for stimulation with tolbutamide (Löfler el al., 1969). Although a similar and systematic comparison has not been performed with the kind of islets used here, graded responses of insulin release were observed with glibenclamide concentrations varying between 0.2 and 200 uM (Hellman et al., 1969). The lowest intravenous dose capable of lowering the blood sugar in mice has been reported to be 400 times higher for tolbutamide than for glibenclamide (Bänder et al., 1969).

In discussing the present results, we shall assume that the degradation of sulfonylureas was neglible in comparison with the amounts of these drugs that were taken up by the islets. There are no data available to prove the validity of this assumption. Control experiments revealed, however, that the radioactive carbon atom of glibenolamide was not significantly lost by oxidation to ${ }^{14} \mathrm{CO}_{2}$. This observation is in accordance with previous reports that $8 \mathrm{~h}$ after administration of ${ }^{14} \mathrm{C}$-labelled glibenclamide to rabbits, dogs, and rats, less than $1 \%$ of the radioactivity had been lost through respiration (Heptner et al., 1969).

The molecular weight of ionized drugs is often too large to permit diffusion through the pores of plasma membranes (Hogben, 1971). An exception may be observed in hepatocytes, which permit the passage of ions with relatively high molecular weights. It is therefore not surprising that significant amounts of tolbutamide have been observed in bile (Bänder and Scholz, 1956), whereas the drug was reported to be restricted to the extracellular space in eviscerated and nephrectomized rabbits (Wick et al., 1956) as well as in man (Stowers et al, 1958). We have previously reported that pancreatic islets incubated in the presence of albumin did not take up more tolbutamide than was explicable in terms of a passive distribution of the compound in the extracellular space (Hellman et al., 1971a). This result indicated that tolbutamide did not penetrate the $\beta$-cells, although it could not be ruled out that the drug entered in amounts below the detection limit of our technique. It was consequently suggested that sulfonylureas act on a receptor in the $\beta$-cell plasma membrane. The same arguments cannot be applied to the results obtained with glibenclamide, since in the absence of albumin the uptake of this drug was greater than what corresponded to the 3-O-methyl-D-glucose space. These observations are in agreement with those of Howell and Lacy (1969), who reported that glibenclamide did not behave as an extracellular space marker in rat islets. From these data alone, no conelusion can be drawn concerning the ability of glibenclamide to penetrate the $\beta$-cells, since it is not known how much of the drug was bound to plasma membranes. However, some indirect information may be extracted from the observed effects of PCMBS, antimycin A and chlorpromazine. These compounds increased the islet uptake of sucrose, which suggests that they make the $\beta$-cells more permeable. Millimolar concentrations of chlorpromazine have previously been reported to exert a lytic effect on rat islet cells (Orci et $a l ., 1972$ ). If the sulfonylureas are normally restricted to the outside of the $\beta$-cells, an increased membrane permeability could well result in an increased uptake of the drugs. The stimulatory effects of PCMBS, antimycin $A$ and chlorpromazine on the islet aptake of glibenclamide and tolbutamide are therefore in agreement with the hypothesis that under normal conditions the sulfonylureas do not readily penetrate the $\beta$-cell plasma membrane. This interpretation is supported by the failure of PCMBS, antimycin A and chlorpromazine to stimulate the uptake of glibenclam. ide by subcellular particles of disintegrated islets.

The time-curves for loss of label from islets preloaded with radioactive sulfonylureas indicate that mast of the uptake is easily reversible. This is in line with the observation that the islet uptake of sulfonylureas was markedly reduced when albumin was present in the incubation medium; it is well known that sulfonylureas bind strongly to serum proteins (Judis, 1972). The concentration of albumin used in the present study, $3 \mathrm{mg} / \mathrm{ml}$, is not higher than that thought to be present in the interstitial tissue fluid and considerably lower than that in serum. Insofar as the islet uptake of sulfonylureas is related to their hypoglycemic action, our results are compatible with the idea that the therapeutic effect may be potentiated by compounds which are able to displace the drugs from serum albumin (Judis, 1972). The distribution of glibenolamide in the mouse has previously been studied with whole body autoradiography, which did not reveal any concentration of the drug in the pancreatic islets as compared with blood (Hellman et al., 1969). This result agrees well with the present observation that the glibenclamide space did not exceed that of 3-O-methyl-D-glucose in islets incubated in the presence of serum albumin.

In view of the non-specific affinity of sulfonyl. ureas for proteins, the marked uptake of glibenclamide by islets incubated in albumin-free media should not necessarily be understood as specific binding to the hypothetical sulfonylurea receptor in the $\beta$-cells. Nevertheless, we may of course ask whether the much greater uptake of glibenclamide than of tolbutamide is related to the greater potency of glibenclamide as an insulin secretagogue (Löffler et al., 1969). Studying the perfused rat pancreas, Loubatières (1968) observed a difference between tolbutamide and glibenclamide with regard to the "turn-off" kinetics of insulin release; the stimulatory action of glibenclamide persisted for a longer time after withdrawal of the drug. As pointed out by Grodsky (1968), this difference does 
not prove that the $\beta$-cells have a better "memory" for glibenclamide than for tolbutamide, since it was not known how rapidly the two drugs disappeared from the perfused pancreas. In the present study there was a slower washout of glibenclamide than of tolbutamide from islets preloaded with the sulfonylureas.

There are previous reports that sulfonylureas affect glucose metabolism, oxygen consumption, and cyclic nucleotide phosphodiesterase activity in the pancreatic islets (Hellman et al., 1969; Stork et al., 1969; Montague and Taylor, 1969; Asheroft et al., 1970; Asheroft et al., 1972). It has also been suggested that the insulin-releasing effect of sulfonylureas may be related to their ability to uncouple oxidative phosphorylation and alter the "phosphate potential" in the $\beta$-cells (Hellman et al., 1969; Hellman, 1970). The latter idea was an attempt to explain the action of sulfonylureas in a manner that would be theoretically economical in not requiring the assumption of regulatory mechanisms for insulin release other than glucose metabolism. Although subsequent studies have indicated that such attempts may be unduly monolithic (Hellman et al., $1971 \mathrm{c})$, further experiments appear necessary in order to assess the importance of the metabolic alterations observed in islets exposed to sulfonylureas. It should be pointed out that the hypothesis that these drugs act primarily on the $\beta$-cell plasma membrane has no implications as to the number and nature of effects that may arise from binding to the hypothetical receptor. It seems possible that such binding could result in intracellular metabolic effects which are significant for, or consequences of, the stimulated insulin release.

Acknowledgements. We thank Farbwerke Hoechst A.G., Frankfurt/M., Germany, for a gift of ${ }^{14} \mathrm{C}$-labelled glibenclamide, Schering Corp., Bloomfield, N.J., U.S.A., for donating diazoxide and $\mathrm{AB}$ Leo, Helsingborg, Sweden, for donating chlorpromazine. The work was financially supported by The Swedish Medical Research Council $(12 \times-562 ; 12 \times-2288)$. Mrs Monica Englund, Miss Karin Janze, and Miss Barbro Svedén contributed with their skilful technical assistance.

\section{References}

Ashcroft, S.J.H., Hedeskov, C.J., Randle, P.J.: Glucose metabolism in mouse pancreatic islets. Biochem. J. 118, $143-154(1970)$.

Asheroft, S.J.H., Randle, P.J., Täljedal, I.-B.: Cyclic nucleotide phosphodiesterase activity in normal mouse pancreatic islets. FEBS Letters 20, 263-266 (1972).

Bänder, A., Pfaff, W., Schmidt, F.H., Stork, H., Schröder, H.G.: Zur Pharmakologie von $H B$ 419, einem neuen, stark wirksamen oralen Antidiabeticum. Arzneimittel-Forsch. 19, 1363-1368 (1969).

Bänder, A., Scholz, J.: Spezielle pharmakologische Untersuchungen mit D 860. Dtsch. med. Wschr. 81, 889-891 (1956).

Bloom, G.D., Hellman, B., Idahl, L.-A., Lernmark, Å., Sehlin, J., Täljedal, I.-B.: Effects of organic mercurials on mammalian pancreatic $\beta$-cells: insulin release, glucose transport, glucose oxidation, membrane permeability, and ultrastructure. Biochem. J. 129, 241-254 (1972).
Grodsky, G. M.: Discussion at the second Capri conference. Acta diabet. lat. 5 (suppl. 1), 256-259 (1968).

Grodsky, G.M.: Insulin and the pancreas. Vitam. and Horm. 28, 37-101 (1970).

Hellerström, C.: A method for the microdissection of intact pancreatic islets of mammals. Acta endocr. (Kbh.) $45,122-132$ (1964).

Hellman, B.: Methodological approaches to studies on the pancreatic islets. Diabetologia 6, 110-120 (1970).

Hellman, B., Idahl, L.-A., Danielsson, A.: Adenosine triphosphate levels of mammalian pancreatic $\beta$-cells after stimulation with glucose and hypoglycemic sulfonylureas. Diabetes 18, 509-516 (1969).

Hellman, B., Idahl, L.-A., Tjälve, H., Danielsson, A., Lernmark, A.: Beobachtungen zum Wirkungsmechanismus des hypoglykämisch wirksamen Sulfonylharnstoff-Präparates HB 419. Arzneimittel-Forsch. 19, $1472-1476$ (1969).

Hellman, B., Sehlin, J., Täljedal, I.-B.: The pancreatic $\beta$-cell recognition of insulin secretagogues: II. Site of action of tolbutamide. Biochem. Biophys. Res. Comm. 45, 1384-1388 (1971a).

Hellman, B., Sehlin, J., Täljedal, I.-B.: Transport of $\alpha$-aminoisobutyric acid in mammalian pancreatic $\beta$ cells. Diabetologia 7, 256-265, (1971 b).

Hellman, B., Sehlin, J., Täljedal, I.-B.: Effects of glucose and other modifiers of insulin release on the oxidative metabolism of amino acids in micro-dissected pancreatic islets. Biochem. J. 123, 513-521 (1971c).

Heptner, W., Kellner, H.-M., Christ, O., Weirauch, D.: Metabolismus von HB 419 am Tier. ArzneimittelForsch. 19, 1400-1404 (1969).

Hogben, C.A.M.: Biological membranes and their passage by drugs. In: Concepts in Biochemical Pharmacology, ed. by B.B. Brodie and J.R. Gillette, pp. 1-8. Berlin, Heidelberg, New York: Springer 1971.

Howell, S.L., Lacy, P.E. : Studies on the effect of HB 419 (glibenclamide) on isolated islets and granules. Horm. Metab. Res. 1, 45-47, (1969).

Judis, J.: Binding of sulfonylureas to serum proteins. J. Pharm. Sci. 61, 89 - 93 (1972).

Kaniuga, Z., Bryla, J., Slater, E.C.: Inhibitors around the antimycin-sensitive site in the respiratory chain. In: Inhibitors. Tools in Cell Research, ed. by T. Bücher and H. Sies, pp. 282-300. Berlin, Heidelberg, New York: Springer 1969.

Lernmark, A.: Isolated mouse islets as a model for studying insulin release. Acta diabet. lat. 8, 649 _679 (1971).

Löffler, G., Trautschold, I., Schweiter, T., Lohmann, E.: Zur Wirkung von HB 419 und Tolbutamid in isolierten Langerhans'schen Inseln der Ratte. ArzneimittelForsch. 19, $1469-1472$ (1969).

Loubatieres, A.: Stimulators and inhibitors of insulin secretion, physiological and pharmacological interferences, synergisms and antagonisms. Acta diabet. lat. 5 (suppl. 1), 220-252 (1968).

Lowry, O.H., Rosebrough, N.J., Farr, A.L., Randall, R.J.: Protein measurement with the Folin phenol reagent. J. biol. Chem. 193, 265-275, (1951).

Montague, W., Taylor, K.W.: Islet-cell metabolism during insulin release. Effects of glucose, citrate, octanoate, tolbutamide, glucagon and theophylline. Biochem. J. 115, 257-262 (1969).

Orci, L., Ammon, H.P.T., Steinke, J.: The effect of chlorpromazine (CPZ) on insulin release from isolated pancreatic rat islets: a correlated morphological and biochemical study. Diabetologia 8, 61 (1972). 
Stork, H., Schmidt, F.H., Westman, S., Hellerström, C. Action of some hypoglycaemic sulfonylureas on the oxygen consumption of isolated panereatic islets of mice. Diabetologia 5, 279-283 (1969).

Stowers, J.M., Mahler, R.F., Hunter, R.B.: Pharmacology and the mode of action of the sulphonylureas in man. Lancet 1958 I, 278-283.
Wick, A.N., Britton, B., Grabowski, R.: The action of a sulfonylurea hypoglycemic agent (orinase) in extrahepatic tissues. Metabolism 5, 739-743 (1956).

Prof. Bo Hellman

University of Umea

Dept. of Histology

S.90187 Umea

Sweden 